\title{
PERAWATAN PAYUDARA DAN PIJAT OKSITOSIN MENINGKATKAN PRODUKSI ASI PADA IBU POST PARTUM PRIMIPARA
}

\author{
Ernawati Tri Handayani', Ernik Rustiana² \\ 1 Prodi D3 Kebidanan Universitas Tulungagung \\ Email: erna.th29@gmail.com \\ 2Prodi D3 Kebidanan Universitas Tulungagung \\ Email: enik.rustiana14@gmail.com
}

\begin{abstract}
BackgroundThe pain experienced after childbirth sometimes makes post partum mothers lazy to breastfeed their babies, this can cause breast milk production to not be smooth.

Purpose of the study was to analyze the effects of early mobilization, breast care and oxytocin massage on breast milk production in post partum mothers.

Method The study was conducted at the Sumbergempol Health Center Tulungagung NovemberDecember 2019. Type of comparative analytical research, research design True Experimental Design with one group pre-test-post-test design models. The study population was all post partum mothers. The sampling technique uses simple random sampling with a sample of 18 people. Data were analyzed using the Wilcoxon signed rank test and one way ANOVA.

The results showed that there were effects of breast care and oxytocin massage on breast milk removal in post partum mothers where the value of $p=0,000$ where $p<\alpha(0.05)$.

ConclusionEarly mobilization can accelerate blood circulation in the breast ducts so that milk production will be more smooth. Breast care can stimulate the milk glands so that milk production will be more smooth. By doing oxytocin massage, the oxytocin reflex will increase and will work together with the prolactin reflex in the formation of sufficient milk.

Suggestion Post partum primipara mothers are expected to be more active in seeking information or asking health workers about breast milk production and problems related to milk production and solutions that must be done such as breast care and oxytocin massage, so that post partum primipara mothers and the public can anticipate if it occurs difficulty in the process of breastfeeding.
\end{abstract}

Keywords: Breast Care, Oxytocin Massage, Breastmilk Expenditures

\section{ABSTRAK}

Latar Belakang Sakit yang dialami setelah melahirkan terkadang menjadikan ibu post partum malas menyusui bayinya, hal ini dapat menyebabkan produksi ASI menjadi tidak lancar. Tujuan penelitian menganalisis pengaruh perawatan payudara dan pijat oksitosin terhadap produksi ASI pada ibu post partum.

Tujuan Penelitian dilaksanakan di Puskesmas Sumbergempol Tulungagung bulan NopemberDesember 2019.

Metode Jenis penelitian analitik komparatif, rancangan penelitian True Eksperimental Design dengan model one group pre test - post test desain. Populasi penelitian semua ibu post partum primipara. Teknik sampling menggunakan simple random sampling dengan sample sejumlah 18 orang. Data dianalisis dengan menggunakan uji Wilcoxon signed rank dan one way anova.

Hasil penelitian menunjukkan terdapat pengaruh perawatan payudara dan pijat oksitosin terhadap pengeluaran ASI pada ibu post partum dimana nilai $p=0,000$ dimana $p<a(0,05)$.

Kesimpulan Perawatan payudara dapat merangsang kelenjar air susu sehingga produksi ASI akan semakin lancar. dengan melakukan pijat oksitosin maka reflek oksitosin akan semakin meningkat dan akan bekerja sama dengan reflek prolaktin dalam pembentukan ASI yang cukup.

Saran Ibu post partum primipara diharapkan lebih aktif mencari informasi atau bertanya kepada tenaga kesehatan tentang produksi ASI dan masalah-masalah yang berkaitan dengan produksi ASI serta solusi yang harus dilakukan seperti perawatan payudara dan pijat oksitosin, sehingga ibu post partum primipara dan masyarakat dapat melakukan antisipasi apabila terjadi kesulitan dalam proses menyusui.

Kata Kunci : Perawatan Payudara, Pijat Oksitosin, Pengeluaran ASI 


\section{PENDAHULUAN}

Proses menyusui merupakan keseluruhan proses mulai dari Air susu ibu (ASI) diproduksi sampai proses bayi menghisap dan menelan ASI. Menyusui merupakan cara terbaik untuk memenuhi kebutuhan nutrisi bayi, selain itu proses menyusui dapat membangun hubungan intim dan hangat antara ibu dan anaknya (Cresoft, 2008). Dalam proses menyusui seringkali terjadi masalah selama menyusui diantaranya: payudara bengkak, mastitis, puting tenggelam, ASI belum keluar serta teknik menyusui yang tidak benar berpengaruh terhadap kegagalan menyusui (Roesli, 2013).

Dampak dari masalah tersebut pada ibu yaitu dapat menimbulkan distensi payudara, mastitis, dll. Sedagkan dampak pada bayi, rendahnya pemenuhan kebutuhan nutrisi pada bayi, dapat mempengaruhi proses tumbuh kembang anak dan kebutuhan bayi yang tidak terpenuhi yaitu : rasaa aman, kehangatan dekapan ibu, sentuhan lembut (Saleha, 2015).

Berdasarkan data di Jawa Timur tahun 2014, sebanyak $72,89 \%$ cakupan bayi yang mendapat ASI eksklufsif, bila dibandingkan dengan tahun $2013(68,48 \%)$ cakupan tersebut mengalami peningkatan (Dinkes Jatim, 2015). Di Kabupaten Tulungagung presentasi bayi yang diberi ASI eksklusif selama tahun 2015 sebesar 68,94\% dari jumlah keseluruhan bayi 0-6 bulan yaitu sebanyak 10.326 orang (Dinkes Tulungagung, 2017). Berdasarkan data tersebut diatas cakupan ASI eksklusif pada bayi belum tercapai $100 \%$. Hasil survey pendahuluan yang dilakukan pada tanggal 17 September 2019 di Puskesmas Sumbergempol diketahui bahwa dari 10 ibu post partum hanya 6 ibu yang melakukan pemberian ASI eksklusif dan 4 lainnya memberikan susu formula pada bayinya. Hal tersebut dapat terjadi karena masalah-masalah dalam menyusui seperti kurang lancarnya produksi ASI pada ibu sehingga kebutuhan ASI tidak terpenuhi dan pada akirnya diberikan tambahan ASI seperti susu formula.

Produksi ASI yang kurang dapat ditingkatkat dengan cara farmakologi maupun dengan non farmakologi. Farmakologi adalah dengan menggunakan obat-obatan serta penggunaan susu formula khusus untuk ibu menyusui. Adapun yang non farmakologi dapat dilakukan dengan pola makan dengan gizi seimbang untuk ibu menyusui, mobilisasi dini, dengan pijat oksitosin dan perawatan payudara (Depkes RI, 2016).

Pijat oksitosin setelah melahirkan dapat merangsang keluarnya hormon prolaktin dan oksitosin (Roesli, 2013). Hormon oksitosin sendiri menyebabkan sel otot saluran pembuat susu menjadi berkontraksi sehingga mendorong ASI untuk keluar dan siap untuk dihasap oleh bayi. Selain merangsang produksi ASI pijat bayi juga bermanfaat untuk mengurangi bengkak pada payudara, memberikan kenyamanan pada ibu, mencegah sumbatan ASI dan dapat mempertahankan produksi ASI saat ibu dan bayi sakit (Depkes RI, 2016).

Selain tehnik pijat oksitosin untuk memperlancar produksi ASI juga dapat dengan melakukan perawatan payudara (breast care). Dengan perawatan payudara juga mampu merangsang sekresi hormon oksitosin, sehingga dapat merangsang produksi ASI sedini mungkin. Rangsangan putting susu dan tehnik pemijatan saat dilakukan perawat payudara, mengahasilkan latihan seperti efek saat bayi melakukan hisapan pada payudara ibu sehingga memicu pengeluaran ASI (Tamboyang, 2015).

\section{METODE PENELITIAN}

Penelitian ini termasuk penelitian analitik komparatif dengan rancangan penelitian yang digunakan True Eksperimental Design dengan menggunakan model one group pre test - post test desain. Populasi dalam penelitian ini adalah semua ibu post partum primipara di Puskesmas Sumbergempol Kabupaten Tulungagung pada bulan Nopember- Desember 2019. Teknik sampel yang digunakan adalah probablity sampling dengan metode simple random sampling. Besar sampel ideal menurut hitungan rumus frederer adalah untuk setiap perlakuan 6 orang partum primipara. Sedangkan dalam penelitian ini ada 3 perlakuan, yaitu perawatan payudara, pijat oksiosin dan kontrol, jadi jumlah sampel yang diperlukan adalah 18 orang ibu post partum primipara. Teknik penelitian dilakukan sebagai berikut: 1) Responden adalah ibu primipara yang mengalami gangguan produksi ASI/ produksi ASInya kurang. 2) Produksi ASI diukur 4 kali yaitu 1 kali sebelum perlakuan dan 3 kali setelah perlakuan (perlakuan dilakukan tiap hari selama 3 hari), kemudian diukur rata-rata jumlah produksi ASI, 3) Produksi ASI diukur dengan cara melihat jumlah ASI yang keluar (dalam satuan $\mathrm{ml}$ ) dengan kriteria: Kurang $(<250 \mathrm{ml})$, Normal (250-400 ml), Lebih (> $400 \mathrm{ml}), 4$ ) Perlakuan dilakukan oleh ahli di bidangnya untuk masingmasing jenis perlakuan dan dilakukan oleh 1 orang pada setiap perlakuan, 5) Perlakuan dilaksanakan sesuai dengan prosedur yang telah ditentukan.

Variabel independent adalah perawatan payudara dan pijat oksitosin. Dan variabel 
dependennya adalah pengeluaran ASI pada ibu post partum.

Lokasi penelitian ini dilakukan di Puskesmas Sumbergempol Kabupaten Tulungagung. Waktu penelitian akan dilaksanakan pada bulan November- Desember 2019.

Analisis data bivariate untuk menguji hubungan variabel pengaruh mobilisasi dini, perawatan payudara dan pijat oksitosin terhadap pengeluaran ASI pada ibu post partum primipara menggunakan uji wilcoxon signed rank. Analisis multivariate untuk menguji hubungan antar variabel pengaruh perawatan payudara dan pijat oksitosin terhadap pengeluaran ASI pada ibu post partum primipara menggunakan uji one way anova, dengan penarikan kesimpulan apabila $p$ value < nilai a $(0,05)$ maka $\mathrm{H} 1$ diterima dan $\mathrm{H} 0$ ditolak.

\section{HASIL}

Pengeluaran ASI Sebelum dan Sesudah Perawatan Payudara

Berdasarkan tabel 1 menunjukkan dari 6 responden, seluruh responden yaitu sebanyak 6 responden $(100 \%)$ sebelum perawatan payudara pengeluaran ASInya kurang dan sesudah perawatan payudara pengeluaran ASInya normal.

Tabel 1.

Tabulasi Pengeluaran ASI Sebelum dan Sesudah Perawatan Payudara di Puskesmas Sumbergempol Kabupaten Tulungagung

\begin{tabular}{cccccccccc}
\hline \multirow{2}{*}{$\begin{array}{c}\text { No. } \\
\text { Resp }\end{array}$} & \multicolumn{8}{c}{ Sebelum Perlakuan } & \multicolumn{7}{c}{ Sesudah Perlakuan } \\
\cline { 2 - 9 } & Jumlah & Kreteria & Kode & Hari 1 & Hari 2 & Hari 3 & Rata-rata & Kriteria & Kode \\
\hline 1 & 130 & Kurang & 1 & 260 & 320 & 380 & 320.00 & Normal & 2 \\
2 & 140 & Kurang & 1 & 270 & 330 & 380 & 326.67 & Normal & 2 \\
3 & 125 & Kurang & 1 & 260 & 320 & 390 & 323.33 & Normal & 2 \\
4 & 120 & Kurang & 1 & 260 & 330 & 390 & 326.67 & Normal & 2 \\
5 & 130 & Kurang & 1 & 270 & 340 & 400 & 336.67 & Normal & 2 \\
6 & 160 & Kurang & 1 & 250 & 310 & 370 & 310.00 & Normal & 2 \\
\hline
\end{tabular}

Sumber: data primer penelitian

\section{Pengeluaran ASI Sebelum dan sesudah Pijat Oksitosin}

Berdasarkan table 2 menunjukkan dari 6 responden, seluruh responden yaitu sebanyak 6 responden (100\%) sebelum pijat oksitosin pengeluaran ASInya kurang dan sesudah pijat oksitosin pengeluaran ASInya normal.

Tabel 2.

Tabulasi Pengeluaran ASI Sebelum dan Sesudah Pijat Oksitosin di Puskesmas Sumbergempol Kabupaten Tulungagung

\begin{tabular}{cccccccccc}
\hline \multirow{2}{*}{$\begin{array}{c}\text { No. } \\
\text { Resp }\end{array}$} & \multicolumn{10}{c}{ Sebelum Perlakuan } & \multicolumn{7}{c}{ Sesudah Perlakuan } \\
\cline { 2 - 10 } & Jumlah & Kreteria & Kode & Hari 1 & Hari 2 & Hari 3 & Rata-rata & Kriteria & Kode \\
\hline 1 & 150 & Kurang & 1 & 280 & 330 & 400 & 336.67 & Normal & 2 \\
2 & 170 & Kurang & 1 & 290 & 340 & 420 & 350.00 & Normal & 2 \\
3 & 120 & Kurang & 1 & 290 & 350 & 420 & 353.33 & Normal & 2 \\
4 & 160 & Kurang & 1 & 280 & 350 & 410 & 346.67 & Normal & 2 \\
5 & 110 & Kurang & 1 & 270 & 360 & 430 & 353.33 & Normal & 2 \\
6 & 100 & Kurang & 1 & 260 & 340 & 410 & 336.67 & Normal & 2 \\
\hline
\end{tabular}

Sumber: data primer penelitian

Tabulasi Silang Pengeluaran ASI Sebelum dan Sesudah Tanpa Perlakuan

Berdasarkan tabel 3 menunjukkan dari 6 responden, seluruh responden yaitu sebanyak 6 responden (100\%) sebelum tanpa perlakuan pengeluaran ASInya kurang dan sesudah tanpa perlakuan pengeluaran ASInya tetap kurang. 
Tabel 3.

Tabulasi Pengeluaran ASI Sebelum dan Sesudah Tanpa perlakuan di Puskesmas Sumbergempol Kabupaten Tulungagung

\begin{tabular}{cccccccccc}
\hline \multirow{2}{*}{$\begin{array}{c}\text { No. } \\
\text { Resp }\end{array}$} & \multicolumn{8}{c}{ Sebelum Perlakuan } & \multicolumn{7}{c}{ Sesudah Perlakuan } \\
\cline { 2 - 10 } & Jumlah & Kreteria & Kode & Hari 1 & Hari 2 & Hari 3 & Rata-rata & Kriteria & Kode \\
\hline 1 & 110 & Kurang & 1 & 120 & 120 & 130 & 123.33 & Kurang & 1 \\
2 & 160 & Kurang & 1 & 170 & 160 & 160 & 163.33 & Kurang & 1 \\
3 & 130 & Kurang & 1 & 140 & 140 & 150 & 143.33 & Kurang & 1 \\
4 & 140 & Kurang & 1 & 140 & 140 & 150 & 143.33 & Kurang & 1 \\
5 & 120 & Kurang & 1 & 130 & 120 & 130 & 126.67 & Kurang & 1 \\
6 & 130 & Kurang & 1 & 130 & 130 & 140 & 133.33 & Kurang & 1 \\
\hline
\end{tabular}

Sumber: data primer penelitian

\section{Hasil Uji Statistik}

Tabel 4.

Hasil Uji Statistik Bivariat

\begin{tabular}{lcc}
\hline \multicolumn{1}{c}{ Variabel } & Analisis & $\mathrm{P}$ \\
\hline Pengeluaran ASI sebelum*sesudah Perawatan Payudara & Paired T Test & 0.000 \\
Pengeluaran ASI sebelum*sesudah Pijat Oksitosin & Paired T Test & 0.000 \\
Pengeluaran ASI sebelum*sesudah Tanpa Perlakuan & Paired T Test & 0.015 \\
\hline
\end{tabular}

Sumber: data primer penelitian

Berdasarkan tabel 4 menunjukkan hasil uji paired $t$ test antara pengeluaran ASI sebelum dengan sesudah perawatan payudara didapatkan $p$ $=0,000$ dimana $p<a(0,05)$ yang berarti bahwa ada pengaruh perawatan payudara terhadap pengeluaran ASI pada ibu post partum primipara.

Berdasarkan tabel 4 menunjukkan hasil uji paired $t$ test antara pengeluaran ASI sebelum dengan sesudah pijat oksitosin didapatkan $p=$ 0,000 dimana $p<a(0,05)$ yang berarti bahwa ada pengaruh pijat oksitosin terhadap pengeluaran ASI pada ibu post partum primipara.

Berdasarkan tabel 4 menunjukkan hasil uji paired $t$ test antara pengeluaran ASI sebelum dengan sesudah tanpa perlakuan (kontrol) didapatkan $p=0,015$ dimana $p<a(0,05)$ ada perubahan pengeluaran ASI antara sebelum dan sesudah tanpa perlakuan (kontrol) namun demikian perubahannya tidak berarti karena pengeluaran ASInya tetap dalam kategori kurang.

\section{Uji Normalitas dan Homoginitas}

Uji normalitas dengan menggunakan uji kolmogorov-smirnov test didapatkan nilai P sebagai berikut (hasil analisis terlampir):

Perawatan payudara $\quad: 0,259<0,05$ data berdistribusi normal

Pijat Oksitosin $\quad: 0,216<0,05$ data

berdistribusi normal

Kontrol

berdistribusi normal

$$
: 0,978<0,05 \quad \text { data }
$$

Berdasarkan data tersebut menunjukkan bahwa semua data kelompok perlakuan berdistribusi normal.

Sedangkan uji homoginitas dengan menggunakan uji lavene test didapatkan nilai $p=$ $0,000<$ nilai $a=0,05$, artinya data kelompok data sampel adalah homogen atau memiliki varian yang sama.

\section{Hasil Uji Statistik Multivariat}

Tabel 5.

Hasil Uji Statistik Multivariat (Anova)

\begin{tabular}{cccccc}
\hline Produksi Asi & Sumof Squares & df & Mean Square & F & Sig. \\
\hline Between Groups & 165170.3 & 3 & 55056.755 & \multirow{2}{*}{156.271} & \multirow{2}{*}{000} \\
Within Groups & 7046.308 & 20 & 352.315 & & \\
\hline \multicolumn{1}{c}{ Total } & 172216.6 & 23 & & & \\
\hline
\end{tabular}

Sumber: data primer penelitian 
Berdasarkan tabel 5 menunjukkan hasil uji one way anova didapatkan nilai $F$ sebesar 156,271 dan nilai $P=0,000$ lebih kecil dari nilai $\alpha=0,05$. Berdasarkan hasil uji tersebut maka dapat diambil keputusan bahwa terdapat perbedaan antara perlakuan yaitu perawatan payudara, pijat oksitosin dan perlakuan kontrol terhadap pengeluaran ASI pada ibu post partum primipara di Puskesmas Sumbergempol Kabupaten Tulungagung tahun 2019.

Selanjutnya melalui uji post hoc LSD diketahui perbedaan antar kelompok yang dirangkum sebagai berikut:
Perawatan payudara - pijat oksitosin $=$ tidak signifikan

Perawatan payudara - kontrol = signifikan

Pijat oksitosin - kontrol = signifikan

Dengan demikian disimpulkan bahwa antar kelompok perlakuan tidak mempunyai perbedaan tetapi semua perlakuan memiliki perbedaan signifikan terhadap kelompok kontrol.

Selanjutnya uji post hoc Duncan dapat dilihat pada tabel dibawah ini:

Tabel 6.

Hasil Uji Post Hoc Duncan

\begin{tabular}{lllcc}
\hline & \multirow{2}{*}{ Perlakuan } & \multirow{2}{*}{$\mathrm{N}$} & \multicolumn{2}{c}{ Subset for alpha $=.05$} \\
\cline { 4 - 4 } duncan $^{3}{ }^{3}$ & Kontrol & 6 & 7.2200 & 2 \\
& Perawatan Payudara & 6 & & 189.7233 \\
& Pijat Oksitosin & 6 & & 211.1117 \\
& Sig. & & 1.000 & .075 \\
\hline
\end{tabular}

Means for groups in homogeneous subsets are displayed

a. Uses Harmonic Mean Sample Size $=6.000$

Berdasarkan tabel 6 diketahui bahwa dari nilai harmonic mean yang dihasilkan antara kelompok perlakuan dan kelompok kontrol berada dalam kolom subset yang berbeda. Hal ini menunjukkan bahwa ada perbedaan yang signifikan antara kelompok perlakuan dan kelompok kontrol. Dan pada kelompok perlakuan menunjukkan bahwa pijat oksitosin memiliki nilai mean tertingi. Hal ini menunjukkan bahwa peningkatan pengeluaran produksi ASI terbanyak adalah pada perlakuan pijat oksitosin.

\section{PEMBAHASAN}

Produksi ASI pada ibu post partum primipara di Puskesmas Sumbergempol Kabupaten Tulungagung sebelum perawatan payudara

Hasil penelitian menunjukkan dari 6 responden seluruhnya yaitu 6 responden (100\%) sebelum perawatan payudara produksi ASI-nya kurang.

Menurut Ambarwati (2015), perawatan payudara adalah suatu cara yang dilakukan untuk merawat payudara agar air susu keluar dengan lancar. Perawatan payudara hendaknya dimulai sedini mungkin, yaitu 1-2 hari setelah bayi dilahirkan dan dilakukan 2 kali sehari, karena pada masa nifas ini kemungkin terjadinya kesulitan dalam menyusui akan lebih banyak.
Menurut Sulistyawati, beberapa kriteria yang digunakan sebagai acuan untuk menilai banyaknya jumlah produksi ASI adalah: payudara terasa tegang sebelum disusukan, ASI dapat merember keluar bila produksinya banyak, berat badan bayi akan naik sesuai dengan usianya (Sulistyawati, 2013).

Berdasarkan fakta diatas seluruh responden adalah ibu primipara sehingga mereka mempunyai pengalaman yang kurang dalam melakukan perawatan payudara. Bila dilihat dari pekerjaan ibu juga rata-rata usia produktif sehingga mereka tidak punya waktu untuk melakukan perawatan payudara. Sehingga mengakibatkan produksi ASlnya kurang.

\section{Produksi ASI pada ibu post partum primipara di Puskesmas Sumbergempol Kabupaten Tulungagung sebelum pijat oksitosin}

Hasil penelitian menunjukkan dari 6 responden seluruhnya yaitu 6 responden (100\%) sebelum pijat oksitosin produksi ASI-nya kurang. Air susu ibu (ASI) adalah makanan bernutrisi dan berenergi tinggi yang mudah untuk dicerna. ASI memiliki kandungan yang dapat membantu penyerapan nutrisi (Mardiah, 2016). ASI merupakan cairan berwarna putih yang berasal dari ibu yang sedang hamil atau keluar saat bayi lahir yang 
banyak sekali kandungan nutrisinya (Binafsika, 2014).

Hormon oksitosin merupakan hormone yang disimpan di dalam lobus posterior pituitary dan dibentuk oleh sel neuronal nuclei hipotalamik. Oksitosin bekerja sebagai penginjeksi ASI dan membuat uterus berkontraksi (Suherni, Hesty \& Anita, 2016).

Kriteria yang dapat digunakan sebagai patokan untuk mengetahui kecukupan ASI yaitu ASI yang dapat merembes keluar melalui putting bila jumlahnya banyak, payudara terasa tegang sebelum disusukan, bayi akan mengalami peningkatan berat badan sesuai usia (Sulistyawati, 2013).

Berdasarkan fakta Berdasarkan fakta ibu primipara adalah bekerja, hal ini bisa menjadi factor penyebab ibu promipara tidak pernah mendapatkan pijat oksitosin. Selain itu dengan kesibukan bekerja ibu primipara menjadi minim mendapatkan informasi tentang pijat oksitosin, hal ini yang memungkkinkan produksi ASI yang sedikit pada ibu primipara, meskipun banyak faktor lain yang secara fisiologis dan patologis dapat mempengaruhi produksi ASI.

\section{Produksi ASI pada ibu post partum primipara di Puskesmas Sumbergempol Kabupaten Tulungagung sesudah perawatan payudara}

Hasil penelitian menunjukkan dari 6 responden seluruhnya yaitu 6 responden (100\%) sesudah perawatan payudara produksi ASI-nya normal. Hasil penelitian juga menunjukkan dari 6 responden, seluruh responden yaitu sebanyak 6 responden $(100 \%)$ sebelum perawatan payudara pengeluaran ASlnya kurang dan sesudah perawatan payudara pengeluaran ASInya normal.

Manfaat perawatan payudara menurut Ambarwati (2015) adalah menjaga kebersihan payudara terutama puting susu, merangsang kelenjar air susu, sehingga produksi ASI lancar, mengetahui kelainan puting susu secara dini dan melakukan usaha untuk mengatasinya, serta melenturkan dan menguatkan puting agar bayi dapay menyusu dengan baik.

Selama penelitian, dari 6 ibu primipara yang dilakukan perawatan payudara semuanya mengalami peningkatan produksi ASI sehingga produksi ASInya menjadi normal yaitu diatas $200 \mathrm{ml}$ dalam sehari. Hal ini menunjukkan bahwa dengan dilakukannya perawatan payudara selama penelitian 3 hari maka produksi ASI pada ibu post partum primipara dapat meningkat sebagaimana normalnya penyeluaran ASI pada ibu menyusui. Hal ini dikarenakan tehnik pemijatan dan rangsangan putting susu pada perawatan payudara merupakan latihan yang efeknya seperti hisapan bayi sehingga memicu pengeluaran $\mathrm{ASI}$.

\section{Produksi ASI pada ibu post partum primipara di Puskesmas Sumbergempol Kabupaten Tulungagung sesudah pijat oksitosin}

Hasil penelitian menunjukkan dari 6 responden seluruhnya yaitu 6 responden (100\%) sesudah pijat oksitosin produksi ASI-nya normal. Hasil penelitian juga menunjukkan dari 6 responden, seluruh responden yaitu sebanyak 6 responden (100\%) sebelum pijat oksitosin pengeluaran ASInya kurang dan sesudah pijat oksitosin pengeluaran ASInya normal.

Hisapan pada bayi akan menghasilkan dua reflek yang akan menyebabkan pengeluaran ASI pada waktu dan jumlah yang tepat (Bobak, 2015). Untuk merangsang reflek oksitosin (let down reflex) salah satunga dengan melakukan pijat oksitosin. Dengan pijat oksitosin juga bisa membuat ibu menjadi nyaman, mencegah bengkak payudara, mengurangi sumbatan pada ASI dan bisa mempertahankan produksi ASI (Depkes RI, 2014).

Selama penelitian, dari 6 ibu post partum primipara yang dilakukan pijat oksitosin semuanya mengalami peningkatan produksi ASI, produksi ASInya menjadi normal yaitu diatas $200 \mathrm{ml}$ dalam sehari. Hal ini menunjukkan bahwa dengan dilakukannya pijat oksitosin selama penelitian 3 hari maka produksi ASI pada ibu post partum primipara dapat meningkat sebagaimana normalnya penyeluaran ASI pada ibu menyusui. Oksitosin juga berperan merangsang kontraksi rahim, sehingga plasenta dapat cepat keluar dan mencegah terjadinya perdarahan post partum. Hal terpentingnya adalah ASI akan keluar dengan maksimal bila hormon prolaktin yang dihasilkan dari hisapan bayi juga dibantu oleh hormon oksitosin dari pijat oksitosin dan perawatn payudara. Bila kedua refleks ini tidak bekerja dengan baik maka bayi tidak akan mendapatkan ASI yang mencukupi.

Pengaruh perawatan payudara terhadap
produksi ASI pada ibu post partum primipara di
Puskesmas
$\begin{gathered}\text { Tulungagung } \\ \text { Hasil penelitian menunjukkan dari } 6\end{gathered}$ responden, seluruh responden yaitu sebanyak 6 responden $(100 \%)$ sebelum perawatan payudara pengeluaran ASInya kurang dan sesudah perawatan payudara pengeluaran ASInya normal. Hasil uji paired $t$ test antara pengeluaran ASI sebelum dengan sesudah pijat oksitosin didapatkan $p=0,000$ dimana $p<a(0,05)$ sehingga $H 0$ ditolak 
yang berarti bahwa ada pengaruh pijat oksitosin terhadap pengeluaran ASI pada ibu post partum. Adapun perubahan pengeluaran ASI yaitu sebelum dilakukan pijat oksitosin pengeluaran ASInya kurang dan sesudah dilakukan pijat oksitosin pengeluaran ASInya normal.

Perawatan payudara mempunyai peranan penting untuk mencegah terjadinya masalah dalam menyusui. Dengan perawatan payudara akan merangsang produksi hormon oksitosin sehingga ibu dapat menghasilkan ASI sedini mungkin. Dengan tehnik pemijatan pada perawatan payudara yang dilakukan dengan benar akan merangsang pengeluaran ASI, karena latihan rangsangan pada putting susu pada perawatan payudara seperti latihan hisapan yang dilakukan oleh bayi (Tamboyang, 2013).

Cara terbaik untuk merangsang kelenjar payudara menghasilkan susu yang banyak adalah dengan benar-benar mengosongsakn kedua payudara pada saat menyususi. Bila payudara belum kosong sepenuhnya bisa dikosongkan dengan dipompa atau di peras. ASI yang diperas juga bisa diberikan pada bayi baik langsung maupun disimpan dulu di dalam lemari es. Hal yang menyebabkan payudara tidak dapat dihisap habis diantaranya putting susu lecet, bayi lemah menghisap, produksi ASI yang berlebih (Indiarti, 2014).

Berdasarkan fakta, teori dan kajian diatas menunjukkan bahwa perawatan payudara dapat memberikan efek yang signifikan meningkatkan produksi ASI pada ibu post partum primipara. Hal tersebut dikarenakan bahwa dengan melakukan perawatan payudara maka akan merangsang kelenjar air susu serta dapat mengetahui kelainan payudara sehingga dapat dilakukan usaha untuk mengatasinya. Dengan demikian maka produksi ASI akan semakin lancar.

\section{Pengaruh pijat oksitosin terhadap produksi ASI pada ibu post partum primipara di Puskesmas Sumbergempol Kabupaten Tulungagung}

Hasil penelitian menunjukkan dari 6 responden, seluruh responden yaitu sebanyak 6 responden (100\%) sebelum pijat oksitosin pengeluaran ASInya kurang dan sesudah pijat oksitosin pengeluaran ASInya normal. Hasil uji paired $t$ test antara pengeluaran ASI sebelum dengan sesudah perawatan payudara didapatkan $p$ $=0,000$ dimana $p<a(0,05)$ sehingga $H 0$ ditolak yang berarti bahwa ada pengaruh perawatan payudara terhadap pengeluaran ASI pada ibu post partum primipara di Puskesmas Sumbergempol Kabupaten Tulungagung. Adapun perubahan pengeluaran ASI yaitu sebelum dilakukan perawatan payudara pengeluaran ASInya kurang dan sesudah dilakukan perawatan payudara pengeluaran ASInya normal.

Isapan bayi saat menyusu dapat merangsang hipofise posterior untuk mengasilkan hormon oksitosin. Oksitosin sendiri akan memacu sel myoepithel disekitar alveoli dan duktus untuk berkontraksi, sehingga ASI akan mengalir dari alveoli ke duktus menuju sinus dan putting susu. Dengan sering menyusi maka dapat memperlancar pengeluaran ASI sehingga dapat mencegah terjadinya bengkak pada payudara ibu.

Salah satu solusi untuk mengatasi produksi ASI yang tidak lancar yaitu dengan pijat oksitosin. Pijat oksitosin dilakukan disepanjang tulang belakang (vertebrata) sampai pada tulang costae kelima dan keenam. Pijat oksitosin dilakukan untuk merangsang produksi hormone oksitosin dan hormone prolaktin pada ibu post partum (Yohmi \& Roesli, 2013).

Berdasarkan fakta, teori dan kajian diatas menunjukkan bahwa pijat oksitosin dapat memberikan efek yang signifikan meningkatkan produksi ASI pada ibu post partum primipara. Hal tersebut dikarenakan bahwa dengan melakukan pijat oksitosin maka reflek oksitosin akan semakin meningkat dan akan bekerja sama dengan reflek prolaktin dalam pembentukan ASI yang cukup.

\section{Pengaruh dominan antara pijat oksitisin dan perawatan payudara terhadap produksi ASI}

Berdasarkan uji post hoc Duncan diketahui bahwa dilihat dari nilai harmonic mean yang dihasilkan antara kelompok perlakuan dan kelompok kontrol berada dalam kolom subset yang berbeda. Hal ini menunjukkan bahwa terdapat perbedaan yang signifikan antara kelompok perlakuan dan kelompok kontrol. Dan pada kelompok perlakuan menunjukkan bahwa pijat oksitosin memiliki nilai mean tertingi. Hal ini menunjukkan bahwa peningkatan pengeluaran ASI terbanyak adalah perlakuan pijat oksitosin.

Pijat oksitosin dilakukan pada tulang vertebrata sampai pada tulang costae kelima keenam untuk merangsang reflek oksitosin (reflex let down) ( Roesli, 2013). Perasaan rileks pada ibu menyusui yang dilakukan pijat oksitosin akan menghasilkan produksi hormon oksitosin yang meningkat. Oksitosin sendiri akan merangsang sel otot disekitar saluran susu berkontraksi sehingga dapat mendorong ASI keluar dan siap untuk dihisap oleh bayi. Dengan pijat oksitosin dapat memberikan kenyamanan pada ibu menyusui, mencegah terjadinya bengkak pada payudara, mengurangi 
pengumbatan pada saluran ASI, dapat mempertahankan produksi ASI dan dapat merangsang pengeluaran hormon oksitosin (Depkes RI, 2016).

Berdasarkan fakta, teori dan kajian diatas menunjukkan bahwa pijat oksitosin memberikan efek yang paling signifikan dalam meningkatkan produksi ASI pada ibu post partum primipara. Hal tersebut dikarenakan bahwa dengan melakukan pijat oksitosin maka reflek oksitosin akan semakin meningkat dan akan bekerja sama dengan reflek prolaktin dalam pembentukan ASI yang cukup. Hormon oksitosin akan merangsal sel otot di sekitar payudara untuk berkonttraksi sehingga akan menyebabkan ASI untuk terdorong keluar dan siap untuk dihisap oleh bayi dengan produksi ASI yang mencukupi.

\section{KESIMPULAN}

Produksi ASI pada ibu post partum primipara di Puskesmas Sumbergempol Kabupaten Tulungagung sebelum perawatan payudara seluruhnya yaitu 6 responden (100\%) produksi ASInya kurang Produksi ASI pada ibu post partum primipara di Puskesmas Sumbergempol Kabupaten Tulungagung sebelum pijat oksitosin seluruhnya yaitu 6 responden (100\%) produksi ASI-nya kurang Produksi ASI pada ibu post partum primipara di Puskesmas Sumbergempol Kabupaten Tulungagung sesudah perawatan payudara seluruhnya yaitu 6 responden (100\%) produksi ASInya normal.Produksi ASI pada ibu post partum primipara di Puskesmas Sumbergempol Kabupaten Tulungagung sesudah pijat oksitosin seluruhnya yaitu 6 responden (100\%) produksi ASI-nya normal.Ada pengaruh perawatan payudara terhadap pengeluaran ASI pada ibu post partum primipara di Puskesmas Sumbergempol Kabupaten Tulungagung dimana nilai $p=0,000$ dimana $p<a$ $(0,05)$.Ada pengaruh pijat oksitosin terhadap pengeluaran ASI pada ibu post partum primipara di Puskesmas Sumbergempol Kabupaten Tulungagung dimana nilai $p=0,000$ dimana $p<a$ $(0,05)$.Nilai harmonic mean yang dihasilkan antara kelompok perlakuan dan kelompok kontrol berada dalam kolom subset yang berbeda. Pijat oksitosin memiliki nilai mean tertingi. Hal ini menunjukkan bahwa peningkatan pengeluaran ASI pada ibu post partum primipara di Puskesmas Sumbergempol Kabupaten Tulungagung terbanyak adalah perlakuan pijat oksitosin

\section{SARAN}

Pihak instansi kesehatan diharapkan dapat memberikan tambahan wacana tentang masalah menyusui yang dialami selama proses menyusi sehingga dapat mencari alternatif solusi untuk mengurangi keluhan tersebut dengan cara perawatan payudara dan pijat oksitosin.Penelitian ini diharapkan dapat menambah khazanah perbendaharaan penelitian serta dapat menjadi referensi bagi penelitian-penelitian selanjutnya tentang pengaruh antara pijat oksitosin dan perawatan payudara terhadap produksi ASI pada ibu post partum primipara.lbu post partum primipara diharapkan lebih aktif mencari informasi atau bertanya kepada tenaga kesehatan tentang produksi ASI dan masalah-masalah yang berkaitan dengan produksi ASI serta solusi yang harus dilakukan seperti perawatan payudara dan pijat oksitosin, sehingga ibu post partum primipara dan masyarakat dapat melakukan antisipasi apabila terjadi kesulitan dalam proses menyusui.

\section{DAFTAR PUSTAKA}

Ambarwati, Eny Retna dan Wulandari, Diah. 2015. Asuhan Kebidanan Nifas. Yohyakarta: Nuha Medika.

Bobak, Lowdermilk. 2015. Buku Ajar Keperawatan Maternitas. Jakarta: EGC.

Clark et al,. 2013. Panduan Praktis Keperawatan Dasar. Jakarta: EGC.

Chapman. 2016. Persalinan dan Kelahiran Asuh Kebidanan. Jakarta: EGC.

Dep Kes RI. 2016. Manajemen Laktasi. Departemen Kesehatan : Jakarta: Depkes Rl.

Dinkes Kab. Tulungagung. 2017. Profile Kesehatan Kabupaten Tulungagung tahun 2016. Tulungagung: Dinkes Kab. Tulungagung.

Dewi, Vivian N.L. 2013. Asuhan Kebidanan pada Ibu Nifas. Jakarta: Salemba Medika

Hidayat, A. Alimul Aziz. 2014. Metode Penelitian Kebidanan dan Teknik Analisis Data. Jakarta: Salemba Medika.

Huliana, Mellyna. 2013. Perawatan Ibu Pasca Melahirkan. Jakarta: Puspaswara.

Manuaba, 2013. IImu Kebidanan Pengakit Kandungan dan KB. Jakarta: BPSP.

Moechtar, R. 2015. Sinopsis Obstetri. Jakarta: EGC.

Nanda, 2016. Diagnosis Keperawatan Definisi \& Klasifikasi 2015-2017 Edisi Revisi. Jakarta: EGC.

Notoatmodjo, Soekidjo. 2014. Metodologi Penelitian Kesehatan. Jakarta: Rineka Cipta.

Purwanti, 2013. Asuhan Kebidanan Patologi. Yogyakarta: Nuha Medika.

Pitaloka, A. 2016. Menyusui Bayi Anda. Jakarta: PT Dian Rakyat. 
Prawirohardjo, S. 2016. IImu Kebidanan. Jakarta: Yayasan Bina Pustaka Sarwono Prawirohardjo.

Potter \& Perry, 2013. Buku Ajar Fundamental Keperawatan: Konsep,. Proses, Dan Praktik, edisi 4, Volume.2. Jakarta: EGC.

Roesli, U. 2013. Panduan Praktis Menyusu. Jakarta: Sentra Laktasi Indonesia.

Rukiyah, Ai Yeyeh, dkk. 2014. Asuhan Kebidanan III Nifas. Jakarta: Trans Info Media.

Saleha, Sitti. 2015. Asuhan Kebidanan Pada Masa Nifas. Jakarta: Salemba Medika.

Sarwono, Prawirohardjo. 2015: IImu Kebidanan. Jakarta: Yayasan Bina Pustaka Sarwono Prawirohardjo.
Setyowati, Heni, dkk. 2015. Perbedaan Produksi ASI pada Ibu Post Partum Setelah Pemberian Pijat Oksitosin. Jurnal Keperawtaan Soedirman. Volume 10 No. 3, November 2015.

Siregar, S. 2013. Metode Penelitian Kuantitatir. Jakarta: Salemba Medika.

Sugiyono. 2013. Statistika untuk Penelitian. Jakarta: Alfabeta.

Sulistyawati, Ari. 2015. Buku Ajar Asuhan Kebidanan Pada Ibu Nifas. Yogyakarta: Andi Offset.

Tamboyang. 2015. Patofisiologi Untuk Keperawatan. Jakarta: EGC. 